\title{
TITANINIAI IMPLANTAI GYDANT KRŪTINĖS NESTABILUMĄ; PIRMOJI PATIRTIS LIETUVOJE
}

\author{
Ričardas Janilionis ${ }^{1}$, Pierre-Emmanuel Falcoz, ${ }^{2}$ Vytautas Jovaišas $^{1}$, Žymantas Jagelavičius ${ }^{1}$ \\ ${ }^{1}$ Vilniaus universiteto ligoninès Santariškiu kliniku Krūtinès chirurgijos centras, ${ }^{2}$ Strasbüro univer- \\ siteto ligoninès Krütinès chirurgijos skyrius, Prancūzija
}

Raktažodžiai: sternotomija, krūtinkaulio pseudoartrozè, krūtinkaulio osteosintezè, krūtinès nestabilumas, STRATOS.

\begin{abstract}
Santrauka
Krūtinkaulio nesuaugimas yra rimta komplikacija po transsternalinių širdies operacijų bei po traumų. Ligoniai skundžiasi skausmu krūtinejje kvejpuojant, kosint ar judinant pečių juostą. Pakartotinis krūtinkaulio susiuvimas viela gali baigtis nesėkme, ypač asmenims su išryškejjusia osteoporoze.

Autoriai pateikia dviejų ligonių, kurie buvo operuoti dèl krūtinkaulio pseudoartrozès $(1-$ po širdies operacijos, 1 - po traumos), atvejus. Ligonis po širdies operacijos kreipèsi praejjus 48 mènesiams po operacijos, o ligonis su trauminès kilmès krūtinkaulio pseudoartroze - praejjus 24 mėnesiams po eismo įvykio. Abiem ligoniams buvo simptomų triada: skausmas, krūtinkaulio nestabilumas, nebuvo infekcijos požymių. Ligoniai buvo operuoti. Krūtinei stabilizuoti buvo panaudoti titaniniai implantai (Strasbourg Thorax Osteosyntheses System - STRATOS, MedXpert GmbH, Heitersheim, Vokietija). Tai buvo pirmos tokios operacijos Lietuvoje. Pooperacinè eiga buvo sklandi. Ligoniai tirti po operacijos praéjus 2 metams bei 2 ménesiams. Skausmas pranyko abiem ligoniams. Palpuojant ir kvejpuojant krūtinès siena yra stabili.
\end{abstract}

\section{Ivadas}

Krūtinès sienos nestabilumas, atsiradęs po operacijos ar traumos, sukelia daug nepatogumų ligoniui. Esant nesugijusiam krūtinkauliui, simptomatika būna ypač ryški. Dažniausiai krūtinkaulis tinkamai nesugyja po sternotomijos operacijos, dèl komplikuotos traumos ar ji rezekavus dèl naviko.

Vidurinè išilginè sternotomija dažniausiai daroma asmenims su įvairia chirurgine širdies ar tarpuplaučio patologija. Nurodoma $(1,2)$, kad nuo 0,5 iki $5 \%$ asmenų po tokių operacijų krūtinkaulio siūlè gali iširti. Kai kuriems iš jų negelbsti nei pakartotinis krūtinkaulio siuvimas. Yra pasiūlyta keliolika iširusio krūtinkaulio stabilizavimo metodikų (3-8), deja, nè viena jų nèra universali.

Krūtinkaulio trauminis lūžis yra gana reta patologija. Dažniausiai gydant konservatyviai krūtinkaulis sugyja savaime. Nurodoma (9), kad nuo 5 iki 10\% visų kaulų lūžių gijimas gali būti ilgesnis nei paprastai ar komplikuotis kaulo pseudoartroze. Esant krūtinkaulio pseudoartrozei, ligonis būna priverstas mažinti savo fizinę veiklą dèl skausmų bei pečių juostos ribotų judesių. Per ilgesnị laiką pasikeičia ligonio laikysena - pečiai atsikiša, o krūtine ịdumba, atrofuojasi krūtinès priekinès sienos raumenys. Krūtinkaulio

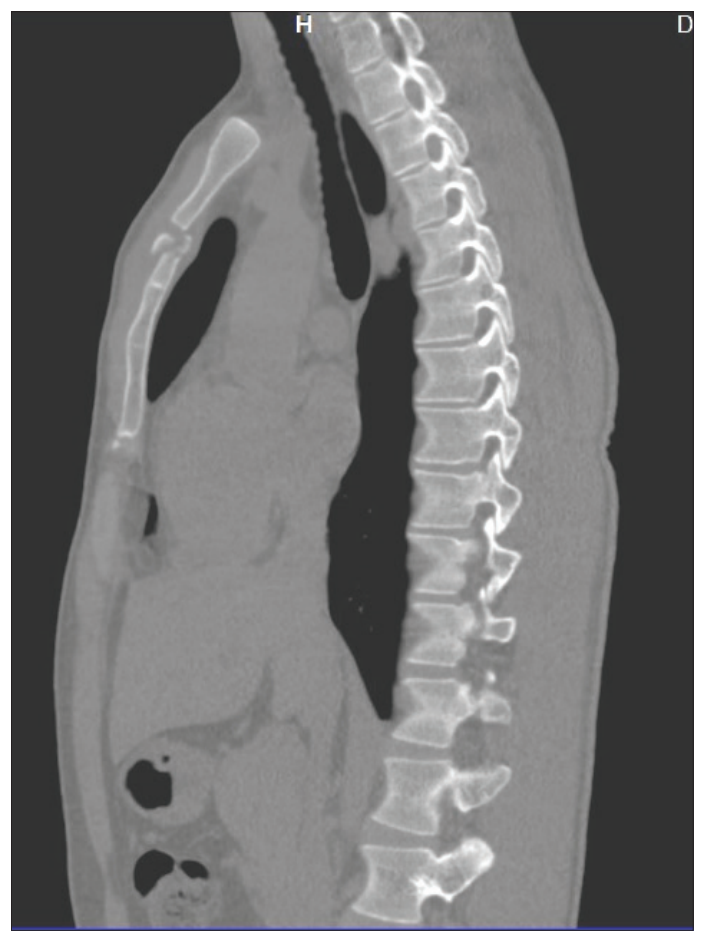

1 pav. Ligonio M.V. krūtinkaulio rentgenograma praèjus 2 mèn. po traumos 




2 pav. Ligonio M.V. krūtinkaulio pseudoartrozė praėjus 2 metams po traumos

pseudoartrozei gydyti taip pat yra pasiūlyta konservatyvių bei chirurginių metodų (10-13).

Darbo tikslas - pateikti dviejų mūsų skyriuje chirurgiškai gydytų ligonių, kuriems buvo krūtinkaulio pseudoartrozé, atvejus. Krūtinkaulio stabilizacijai pirmą kartą Lietuvoje buvo panaudoti titaniniai implantai.

\section{Pirmas klinikinis atvejis}

Ligonis M.V. gimęs 1986 m. nukentejjo eismo avarijoje kaip vairuotojas 2011 metų rugsèjo mėn. Tuomet jam buvo diagnozuotas krūtinès sienos bei krūtinkaulio sumušimas. Skausmams nemažejjant, po 2 mèn. padarytoje rentgenogramoje konstatuotas krūtinkaulio lūžis viršutiniame trečdalyje su poslinkiu (1 pav.). Ligonis toliau buvo gydomas konservatyviai. Po 1,5 metų konservatyvaus gydymo ligonio būklè pagerejjo nežymiai. Vargino skausmai krūtinèje bei pečių juostoje, jos judesiai buvo riboti. Krūtinè įdubo, išryškẻjo didžiujjų krūtinès raumenų atrofija. Padarytoje krūtinkaulio rentgenogramoje (2 pav.) konstatuota kau-

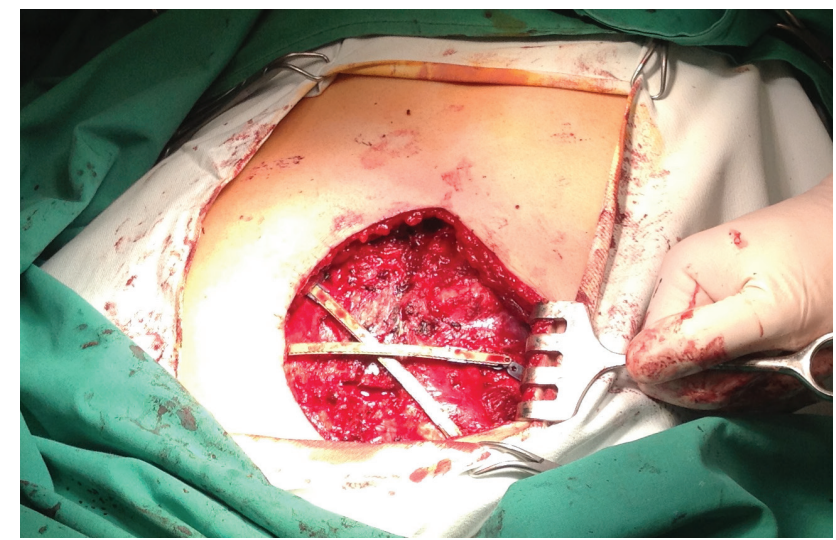

3 pav. Lig. M.V. Operacinis vaizdas po titano konstrukcijų implantavimo

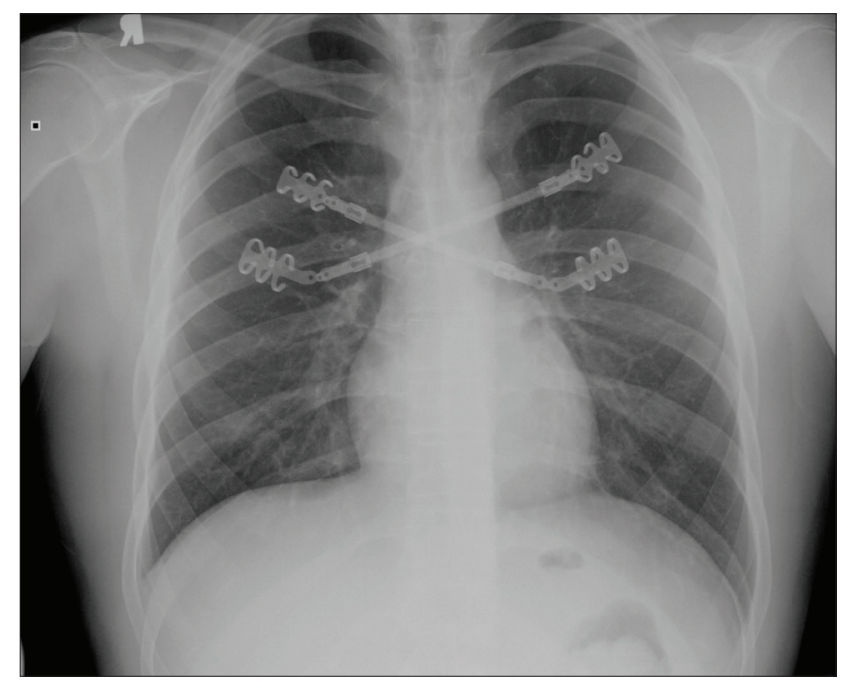

4 pav. Ligonio M.V. pooperacinè krūtinès rentgenograma. Matomos kryžmai implantuotos titaninės konstrukcijos

lo pseudoartrozè. Gydytojų konsiliumo buvo nuspręsta krūtinkaulị stabilizuoti panaudojant titaninius implantus (Strasbourg Thorax Osteosyntheses System-STRATOS, MedXpert GmbH, Heitersheim, Vokietija). Operacija padaryta 2013 metų lapkričio 13 dieną. Per operaciją lūžusio krūtinkaulio galai buvo atnaujinti pašalinant detritą bei randus su fibrinu. Po to krūtinkaulis buvo stabilizuotas sukryžiuotomis titano plokštelemis, kurios buvo pritvirtintos prie II ir III šonkaulių abipus ( 3 pav.). Pooperacinejje rentgenogramoje patologijos nekonstatuota, implantu padètis gera (4 pav.). Ligonis išrašytas ambulatoriniam gydymui po 7 dienų. Ligonis atvyko po 2 mèn. po operacijos. Jaučiasi gerai. Skausmų beveik nekonstatuoja. Pradedama aktyvi reabilitacija. 


\section{Antras klinikinis atvejis}

Ligonis J.H. gimęs 1937 m., 2007 metų lapkričio mèn. buvo operuotas dèl širdies vainikinių arterijų susiaurejjimo. Transsternaliai buvo atlikta vainikinių kraujagyslių šuntavimo operacija. Po operacijos praejus 7 ménesiams ligonis dèl dusulio bei krūtinès skausmų buvo hospitalizuotas pakartotinai. Ištyrus širdį bei vainikines kraujagysles patologijos nekonstatuota. Krūtinès rentgenogramoje buvo matyti, jog viena iš vielų, fiksuojančių krūtinkauli, yra lūžusi. Buvo nuspręsta ligonį operuoti ir papildomai sutvirtinti krūtinkaulị.

Ligonis pakartotinai operuotas 2008 metų gegužès mèn. Per operaciją vielomis buvo papildomai persiūtas krūtinkaulis. Pooperacinis laikotarpis buvo sklandus. Tačiau skausmai krūtinèje neišnyko. Jie ypač suintensyvėdavo kosint bei judinant pečių juostą. Ligonis buvo gydytas ivvairių specialistų, bet be žymesnio efekto. Po kelerių metų (2011 rugsèjo mèn.) padaryta krūtinès kompiuterinè tomograma (KT) atskleidè ligonio skundų priežastį. Joje matyti, kad šešios iš aštuonių krūtinkauli fiksuojančių vielų yra nutrūkusios. Krūtinkaulis po resternotomijos nesugijo; jo fragmentų diastazė apatiniame trečdalyje siekia $20 \mathrm{~mm} \mathrm{(5}$ pav.). Buvo aišku, kad dar viena operacija, panaudojant iprastinį fiksavimo būdą, bus neefektyvi. Todèl buvo nu-

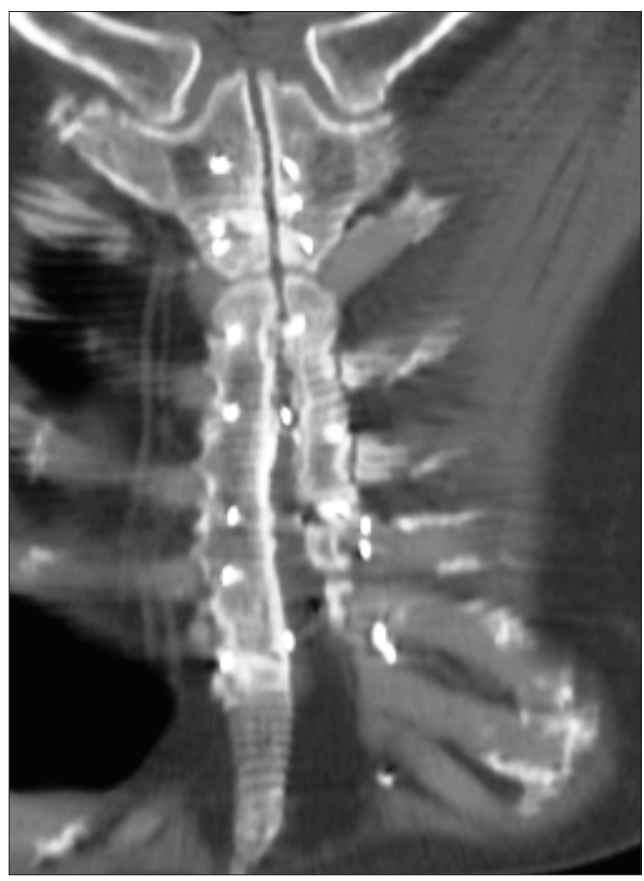

5 pav. Lig. J.H. priešoperacinè krūtinkaulio KT. Krūtinkaulio pseudoartrozè. Apatinèje krūtinkaulio dalyje diastazè tarp kaulo fragmentų siekia 2 $\mathrm{cm}$ spręsta krūtinkaulio stabilizacijai panaudoti titano implantus. Per operaciją buvo panaudoti 6 šonkaulių klipai (fiksatoriai) bei 3 titaninès plokštelès (6 pav.). Per operaciją ligonis prarado apie $200 \mathrm{ml}$ kraujo. Operacija truko 3 val. ir 10 minučių. Pooperacinis laikotarpis sklandus. Pooperacineje krūtinès rentgenogramoje ( 7 pav.) patologijos plaučiuose bei pleuros ertmejje nematyti. Ligonis apžiūrètas praejus pusei metų bei dviem metams po operacijos. Jaučiasi gerai, skausmų krūtinèje nenurodo. Krūtinès siena ligoniui kosint bei palpuojant yra stabili.

\section{Diskusija}

Krūtinès nestabilumas dèl krūtinkaulio patologijos yra nereta komplikacija po traumų ar operacijų. Dažniau-

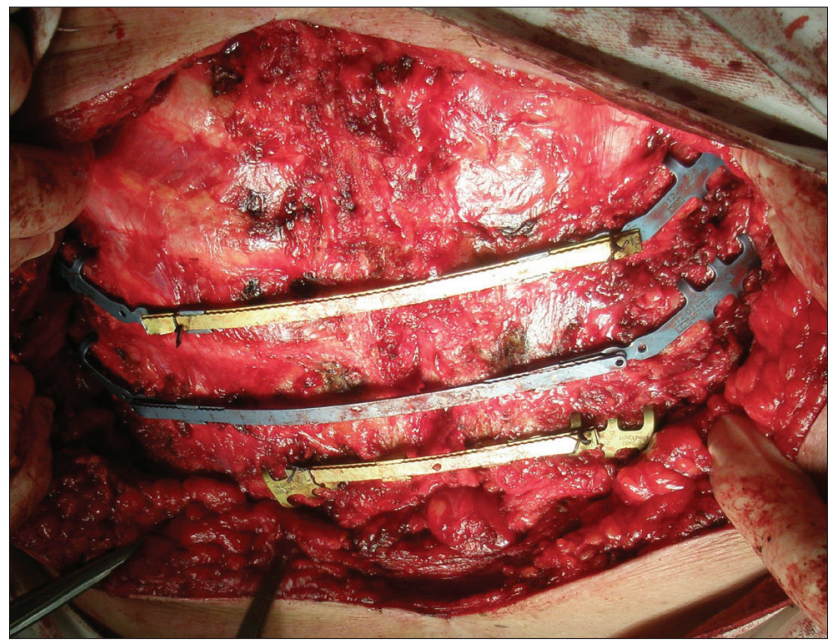

6 pav. Lig. J.H. operacinis vaizdas krūtinkaulį fiksavus titaniniais implantais. Matomos trys titaninès plokštelès bei jas laikantys ant šonkaulių pritvirtinti fiksatoriai. Ligonio galvūgalis viršuje

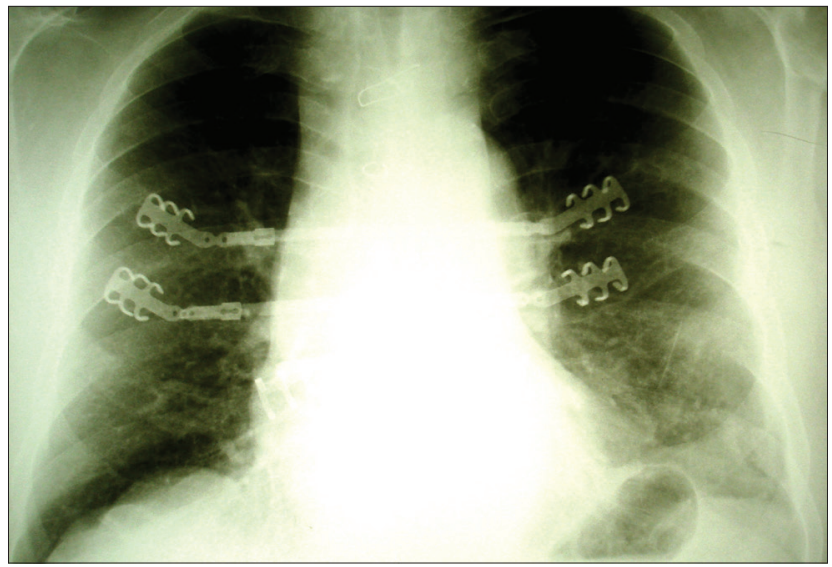

7 pav. Ligonio J.H. krūtinès rentgenograma praejus dvejiem metams po operacijos 
siai krūtinkaulio pseudoartrozė pasitaiko po sternotomijos operacijos. Pakartotinès operacijos transosaliai stabilizuojant kaulą ne visuomet būna sẻkmingos, ypač tuomet, kai ligoniai yra vyresnio amžiaus su išryškèjusia osteoporoze (6). Tuomet krūtinkaulis gali būti stabilizuojamas panaudojant sintetines medžiagas (tinklelius) bei transponuotus raumenų lopus (7). Tačiau atokūs tokių operacijų rezultatai ne visuomet būna patenkinami dèl išliekančio, kad ir nežymaus, krūtinkaulio nestabilumo. Visuotinai sutariama, kad pagrindinis reikalavimas tokioms operacijoms yra tinkamai suartinti krūtinkaulio fragmentai, kad būtų neutralizuotas didžiujų krūtinès raumenų tempimas. Jei kaulo fragmentai liečiasi vienas su kitu, ir tai galima išlaikyti ilgą laiką (kol sugis patologiškai pakitęs kaulas), tuomet operacijos sèkmè yra beveik garantuota. Todèl tapo populiarios įvairios metalinès konstrukcijos, kurios užtikrina anksčiau minètas sąlygas (8).

STRATOS sistema krūtinès sienai stabilizuoti pradèta naudoti palyginti neseniai. Ji pasiteisino gydant asmenis su šviežiais krūtinès kaulų lūžiais, darant radikalias operacijas dèl ịdubos krūtinès (pectus excavatum) bei rekonstruojant krūtinę po radikalių navikų operacijų $(7,8)$.

Kiekvienas implantas sudarytas iš trijų dalių: du fiksatoriai, kurie užspaudžiami ant sveikų šonkaulių abipus, bei juos jungiančios titaninès plokštelès. Tiek fiksatoriai (angl. clips), tiek plokštelès yra trijų dydžių bei trijų išlenkimų. Todèl jie lengvai pritaikomi įvairios konstitucijos bei įvairia patologija sergantiesiems. Titanas, iš kurio pagamintos minètos konstrukcijos, pasižymi visomis savybėmis, kurios reikalingos gydant ligonį su krūtinès nestabilumu. Titano oksidas, padengiantis konstrukcijas, yra ypač atsparus korozijai, o pats metalas ypač stiprus ir lengvas (turi aukščiausią ,strenght to weight" indeksą tarp visu metalų). Prie šio metalo paviršiaus greitai fiksuojasi osteoblastai, vẻliau suformuodami mineralizuotą kaulą, kuris laikui bėgant, priešingai kitiems metalams (apie juos formuojasi metalozès židiniai, dèl to konstrukcijos kauluose pasidaro nestabilios), išlieka tvirtas $(7,13)$.

Kitas titaninių konstrukcijų privalumas yra sąlygiškai menkas jų intensyvumas atliekant radiologinius tyrimus. Atliekant KT tyrimus artefaktų, kurie taip būdingi plieniniams implantams, beveik nebūna. Kadangi titanas nepasižymi feromagnetinėmis savybèmis, jis nèra kliūtis magnetinio rezonanso tyrimams (14).

\section{Išvados}

Tai pirmieji Lietuvoje chirurgiškai gydyti ligoniai su krūtinès sienos nestabilumu, kuriems buvo panaudotos titaninès konstrukcijos. Abu ligoniai po operacijos jaučiasi gerai. Titaniniai implantai yra brangūs, tačiau jie neabejo- tinai pasiteisina gydant asmenis, kuriems kiti chirurginio gydymo metodai efektyviai neužtikrino krūtinès sienos stabilumo. Manome, kad STRATOS titaniniai implantai yra tinkama priemonè, igalinanti ilgam laikui efektyviai stabilizuoti krūtinès ląstą.

\section{Literatūra}

1. Loop FD, Lytle BW, Cosgrove DM, Mahfood S, McHenry MC, Goormastic M, Stewart RW, Golding LAR, Taylor PC. J.Maxwell Chamberlain memorial paper. Sternal wound complications after isolated coronary artery bypass grafting: early and late mortality, morbidity and cost care. Ann Thorac Surg 1990; 49: 179-87.

2. Casha AR, Manche A, Gauci M, Camillieri-Podesta MT, Schembri-Wismayer P, Sant Z, Gatt R, Grima JN Placement of trans-sternal wires according to an ellipsoid pressure vessel model of sternal forces. Interact Cardiovasc Thorac Surg 2012; 14: 283-7.

3. Richardson JD, Franklin GA, Heffley S, Seligson D. Operative fixation of chest wall fractures: an underused procedure? Am Surg 2007; 73: 591-6.

4. Wu LC, Renucci JD, Song HD. Sternal nonunion: a review of current treatments and a new method of rigid fixation. Ann Plast Surg 2005; 54: 55-8.

5. Cicilioni Jr.OJ, Stieg III FH, Papanicolaou G. Sternal wound reconstruction with transverse plate fixation. Plast Reconstr Surg 2005;115:1297-1303.

6. Mansour KA, Thourani VH, Losken A, Reeves JG, Miller Jr. JI, Carlson GW, Jones GE. Chest wall resections and reconstruction: a 25-year experience. Ann Thorac Surg 2002;73:1720-6.

7. Claes L, Eckert-Hubner K, Augat P. The effect of mechanical stability on local vascularization and tissue differentiation in callus healing. J Orthop Res 2002;20:1099-1105.

8. Coonar AS, Qureshi N, Smith I, Reisberg E, Wihlm JM. A novel titanium rib bridge system for chest wall reconstruction. Ann Thorac Surg 2009;87:e46-e48.

9. Bishop GB, Einhorn TA. Current and future clinical applications of bone morphogenetic proteins in orthopaedic trauma surgery. Int Orthop 2007; 31: 721-7.

10. Chintamaneni S, Finzel K, Gruber BL. Successful treatment of sternal fracture nonunion with teriparatide. Osteoporos Int 2010; 21: 1059-63.

11. Axelrad TW, Kakar S, Einhorn TA. New technologies for the enhancement of skeletal repair. Injury 2007; 38SI: S49-S62.

12. Voss B, Bauernchmitt R, Will A, Krane M, Kross R, Brockmann G, Libera P, Lange R. Sternal reconstruction with titanium plates in complicated sternal dehiscence. Eur J Cardiothorac Surg 2008; 34: 139-45.

13. Girsowitz E, Falcoz PE, Santelmo N, Massard G. Does surgical stabilisation improve outcomes in patients with isiolated multiple distracted and painful non-flail rib fracturas. Interact Cardiovasc Thorac Surg 2012; 14(3): 312-5. 
14. Lee MJ, Kim S, Lee SA, Song HT, Huh YM, Kim DH, et al. Overcoming artifacts from metallic orthopaedic implants at high-field-strenght MR imaging and multi-detector CT. Radiographics 2007; 27:791-803.

\section{TITANIUM IMPLANTS IN THE MANAGEMENT OF CHEST INSTABILITY; FIRST EXPERIENCE IN LITHUANIA}

\section{R. Janilionis, P. E. Falcoz, V. Jovaišas, Ž. Jagelavičius}

Key words: sternum fracture, sternal non-union, sternotomy, sternal osteosynthesis, chest instability, STRATOS.

Summary

Sternal nonunion as a result of cardiac intervention or trauma remains a morbid condition with serious sequelae. Patients often report pain with breathing, coughing, and/or movement. The authors present two patients that were diagnosed with sterile nonunion after cardiac procedure (1) or trauma (1). The cardiac patient presented after 48 months after his cardiac procedure; trauma patient presented 24 months after the accident.

Diagnosis was made based on the clinical triad of sternal instability, pain, and absence of infection. Management with open stabilisation using titanium implants (Strasbourg Thorax Osteosyntheses System-STRATOS, MedXpert GmbH, Heitersheim, Germany) was performed in both patients. This was the first experience, using such implants in Lithuania. There was no incidence of subsequent infection. Pain previously due to chest instability completely resolved in both patients. The bone healing was assessed clinically with the absence of instability and pain and follow-up chest radiographs.

Correspondence to: Richard.Janilionis@gmail.com

Gauta 2014-01-06 